\title{
Effect of Registered Potato Seed Piece Fungicides on Tuber-borne Phytophthora infestans
}

\author{
D. A. Inglis, Washington State University-Mount Vernon Research and Extension Unit, 16650 State Route 536, \\ Mount Vernon 98273-9761; M. L. Powelson, Department of Botany and Plant Pathology, Oregon State University \\ 97331, and A. E. Dorrance, Department of Plant Pathology, Ohio Agricultural Research and Development Center, \\ Wooster 44691
}

\begin{abstract}
Inglis, D. A., Powelson, M. L., and Dorrance, A. E. 1999. Effect of registered potato seed piece fungicides on tuber-borne Phytophthora infestans. Plant Dis. 83:229-234.

Curative applications of thiophanate-methyl + mancozeb to blighted seed pieces of three potato (Solanum tuberosum) cultivars significantly reduced the amount of surface area colonized by Phytophthora infestans compared with treatment with thiophanate-methyl or no fungicide under laboratory conditions. Percent blighted tuber surface area over six tests averaged 3.5, 11.4, and $21.2 \%$ for the three treatments, respectively. Seed pieces inoculated with $P$. infestans US-8 or US-11, incubated, and then treated with the same fungicides and planted at Oregon and Washington field sites, respectively, had higher emergence across locations for thiophanate-methyl + mancozeb than for thiophanate-methyl (30 versus 12.5\%). Emergence of healthy thiophanatemethyl + mancozeb-treated seed pieces averaged $93 \%$. When protective applications of these fungicides, mancozeb, or fludioxinil were made to healthy potato seed pieces prior to inoculation with $P$. infestans, plant emergence in the greenhouse was significantly increased with thiophanate-methyl + mancozeb compared with fludioxinil (92 versus 36\%) in Oregon and with thiophanate-methyl or fludioxinil (90 versus 20 and 24\%) in Washington. Inoculation of healthy seed pieces reduced plant stand in all greenhouse tests; however, treatment with thiophanatemethyl + mancozeb or mancozeb alone prior to inoculation resulted in sprout emergence similar to that of the noninoculated control. In a late blight management program, treatment of seed pieces with a registered fungicide that has activity against $P$. infestans contributes to an increase in plant emergence and improved crop uniformity. However, for maximum benefit, the fungicide must be in place before coming in contact with the pathogen.
\end{abstract}

Additional keywords: tuber blight

Several fungicides, captan, mancozeb, maneb, fludioxinil, thiabendazole, and thiophanate-methyl, as well as combinations of these products, can be applied commercially to potato (Solanum tuberosum) seed pieces for control of diseases caused by Fusarium spp., Helminthosporium solani, Pythium spp., and Rhizoctonia solani. Although none of these fungicides target Phytophthora infestans specifically, some also may have activity against this pathogen. Until recently, none of these materials was labeled for management of late blight.

Recent work (14) has demonstrated that $P$. infestans can be spread from diseased to healthy seed pieces during seed handling and cutting operations. Failure to control contamination of seed pieces by $P$. infestans may lead to subsequent disease development due to movement of the fun-

Corresponding author: D. A. Inglis

E-mail: dainglis@ coopext.cahe.wsu.edu

Accepted for publication 28 October 1998.

Publication no. D-1999-0106-01R

(C) 1999 The American Phytopathological Society gus from the contaminated seed piece to the emerging plant $(3,14,15)$.

Fungicides containing ethylenebisdithiocarbamate (EBDC) are known to be effective in suppressing the development of foliar symptoms of late blight (1). Therefore, commercial seed piece fungicides that have an EBDC as one of the active ingredients also may be effective in protecting seed pieces from contamination by $P$. infestans. Conversely, other seed piece fungicides may facilitate the transmission of $P$. infestans from the seed piece to the developing sprout either because they lack efficacy or suppress fungi such as Fusarium spp., which may otherwise compete with $P$. infestans. For example, benzimidazoles and thiophanates have a wide spectrum of antifungal activity against a diverse group of fungi, including Fusarium spp., but not against oomycetes (4). Dorrance et al. (6) treated blighted potato tuber pieces with benomyl to suppress Fusarium and other fungi in order to improve recovery and isolation of $P$. infestans from symptomatic tuber tissues.

Migration of new, aggressive strains of $P$. infestans sometimes has been via the potato seed trade (8). Seed piece fungicides may influence the development of inocu- lum and spread of the fungus from regionto-region. Therefore, it is important that the effect of seed piece fungicides on tuber-borne $P$. infestans is explored. The purpose of this study was to determine (i) if registered fungicides that control tuberborne diseases of potato other than late blight also have activity against tuberborne $P$. infestans, and (ii) whether efficacy is different for applications made to seed pieces with symptoms of tuber blight compared with healthy seed pieces that come into contact with $P$. infestans following the fungicide treatment.

\section{MATERIALS AND METHODS}

Inoculum. $P$. infestans US-8 (A2, metalaxyl-insensitive) in Oregon and US11 (A1, metalaxyl-insensitive, and designated WWA95) in Washington were used in this study. Isolates were grown on rye agar for 10 to 14 days at $18^{\circ} \mathrm{C}$ (Oregon) or on detached potato leaves on moistened filter paper in glass petri dishes at $18^{\circ} \mathrm{C}$ (Washington). Plates were flooded with 5 $\mathrm{ml}$ of sterile distilled water each and gently agitated (Oregon), or leaves were washed in $25 \mathrm{ml}$ of sterile distilled water (Washington) to release sporangia. The density of each suspension was determined using a hemacytometer. The resulting suspension was adjusted with water to $10^{3}$ or $10^{4}$ sporangia per $\mathrm{ml}$ for each experiment. For zoospore inoculum, the flooded plates were placed at $4^{\circ} \mathrm{C}$ for $2 \mathrm{~h}$ to release zoospores, then adjusted to $10^{4}$ zoospores per $\mathrm{ml}$.

Fungicides. Lots of seed pieces weighing approximately $45 \mathrm{~kg}$ were treated with fludioxinil (Novartis, Greensborough, NC) at $1.14 \mathrm{~g}$ a.i., mancozeb (Snake River Chemical Inc., Clean Crop Label, Caldwell, ID) at $36.32 \mathrm{~g}$ a.i., thiophanatemethyl (Gustafson, Inc., Plano, TX) at $11.35 \mathrm{~g}$ a.i., and thiophanate-methyl + mancozeb (Gustafson, Inc.) at $11.35+$ $27.24 \mathrm{~g}$ a.i. The selected formulations were dusts. Seed pieces were placed in a paper or plastic bag with the fungicide and shaken at least $1 \mathrm{~min}$ until uniformly coated so that there was little residual fungicide remaining in the bag. For the Oregon greenhouse experiment, seed pieces were submerged in a liquid formulation of mancozeb (Rohm \& Haas, Philadelphia, PA) at $10,000 \mu \mathrm{g}$ a.i./ml for $15 \mathrm{~min}$, and then air-dried. 
Laboratory experiment. Blighted tubers of Red LaSoda from field plots with severe foliar symptoms of late blight caused by $P$. infestans US-11 (6) were collected at harvest during the 1996 growing season and stored in paper bags at $3.3^{\circ} \mathrm{C}$ under low humidity for 6 months. Only whole tubers with visual symptoms of late blight and without excessive decay by other microorganisms were used for this study. Tubers were cut into $80-\mathrm{g}$ seed pieces.

In addition, 6- or 7-month-old whole healthy seed tubers of Russet Burbank and Russet Norkotah were inoculated with 20 $\mathrm{ml} / 50$ tubers of a suspension of $10^{3}$ sporangia per $\mathrm{ml}$ of $P$. infestans US-11. The suspension was atomized onto each seed tuber using a Badger Precision Air Brush (Grainger, Bothell, WA). Tubers were incubated in covered plastic boxes lined with moistened paper towels in the dark at $20^{\circ} \mathrm{C}$ for 2 days, followed by $15^{\circ} \mathrm{C}$ for 5 to 7 days. After incubation, tubers were cut into seed pieces weighing approximately $80 \mathrm{~g}$.

Symptomatic cut seed pieces of each cultivar were immediately treated with thiophanate-methyl, thiophanate-methyl + mancozeb, or not treated. After fungicides were applied, seed pieces were arranged in a randomized complete block design using plastic boxes with lids as replicates. Each box (replicate) contained eight seed pieces of each treatment; thus, each held 24 seed pieces. There were three replicates for tests with Russet Burbank and Russet Norkotah, and four replicates for tests with Red LaSoda. Cultivars were evaluated in separate tests, and the experiment was performed three times for Russet Burbank, twice for Red LaSoda, and once for Russet Norkotah.

After incubation, each seed piece was visually rated for percent surface area ( 0 to $100 \%$ ) covered with mycelium and sporangia of $P$. infestans. Seed pieces were rated again at 10 to 14 days, but because the seed pieces were typically colonized by bacteria, Fusarium, and other fungi after the longer incubation time, $P$. infestans was more difficult to detect. Therefore, the results of the 5 to 7 day incubation are reported here.

Field experiment. Whole healthy seed tubers were atomized (top side only) with a suspension of $10^{3}$ sporangia per ml of US8 in Oregon and $10^{4}$ sporangia per $\mathrm{ml}$ of US-11 in Washington until uniformly wetted. Noninoculated controls were sprayed with distilled water. Tubers were incubated in covered plastic boxes on moistened paper towels at $15^{\circ} \mathrm{C}$ for 5 to 7 days. Symptomatic tubers were cut transversely so that the resulting seed pieces (56 to 122 g) had one blighted sprout and one healthyappearing sprout. This was done to increase the probability of a sprout emerging aboveground.

Infected seed pieces were treated with thiophanate-methyl or thiophanate-methyl
+ mancozeb as described above. Planting was at the North Willamette Research and Extension Center near Aurora, Oregon, on 31 July 1997, and at the WSU Research and Extension Unit at Mount Vernon, Washington, on 22 May 1997. Treatments were applied to Russet Burbank and Russet Norkotah in Oregon, and to White Rose in Washington. The two fungicide treatments and the nontreated inoculated and nontreated noninoculated controls were arranged in a randomized complete block design with five replications at both locations. Number of seed pieces per treatment was approximately 8 (Oregon) or 25 (Washington). Each plot consisted of one row, $3 \mathrm{~m}$ (Oregon) or $6 \mathrm{~m}$ long (Washington). Rows were spaced on 70(Oregon) or 96-cm centers (Washington), and the distance between seed pieces was $25 \mathrm{~cm}$. Data on percent stand were recorded. When $95 \%$ of the seed pieces had emerged in the noninoculated-nontreated control, the emerging plants in the inoculated plots were monitored at least twice a week for symptoms of late blight. Observations of plant vigor also were made in Oregon. Plants were rated as vigorous if they were equivalent in size to the majority of the plants in the noninoculated treatment.

Greenhouse experiments. Whole healthy seed tubers of Russet Burbank (Oregon) and White Rose (Washington) were cut into single-eye seed pieces weighing approximately 25 to $50 \mathrm{~g}$. Immediately following cutting, they were treated with a fungicide and placed on a greenhouse bench to dry. Four seed piece fungicides (fludioxinil, thiophanate-methyl, thiophanate-methyl + mancozeb, and mancozeb), along with inoculated- and noninoculated-nontreated controls, were included.

A zoospore suspension $\left(10^{4}\right.$ per $\left.\mathrm{ml}\right)$ of US-8 (Oregon), a sporangial suspension $\left(5.2 \times 10^{3}\right.$ per ml) of US-11 (Washington), or distilled water (for the noninoculated controls) was atomized onto each seed piece. Approximately 7.5 to $10 \mathrm{ml}$ was delivered per 50 seed pieces. Immediately after inoculation, seed pieces were planted $6 \mathrm{~cm}$ deep in steam-pasteurized greenhouse potting mix in 600-ml waxed paper cups lined with plastic bags (Oregon) or in commercial potting mix in 10 -cm-diameter $\times 10$-cm-deep plastic pots (Washington). Treatments were arranged on a greenhouse bench in a randomized complete block design and replicated five times. Number of seed pieces per treatment in each replication was 10. After planting, containers were watered to thoroughly moisten the potting mix. Cups or pots were held at a temperature of $17 / 15^{\circ} \mathrm{C}$ (day/night) and watered or misted daily. In Oregon, the plastic bags were pulled and tied over emerging sprouts to encourage late blight lesion development on emerging sprouts. In Washington, 10-day-old plants were misted in plastic tent chambers for $48 \mathrm{~h}$. Beginning 3 weeks after planting and continuing for 2 weeks, data on plant emergence and occurrence of late blight lesions on stems were recorded.

An additional greenhouse experiment in Washington included inoculated and noninoculated fungicide treatments of thiophanate-methyl, thiophanate-methyl + mancozeb, or mancozeb, and both nontreated inoculated and noninoculated controls. In the first test in November 1997, healthy seed tubers of White Rose produced during the 1996 growing season were used; whereas seed tubers of White Rose grown in 1997 were used in the test in February 1998. Seed pieces were cut to approximately $28 \mathrm{~g}$ and immediately dusted with the fungicides. Inoculation of treated seed pieces was by atomization with suspensions of US-11 at 4.8 and $5.0 \times 10^{3}$ sporangia per $\mathrm{ml}$ for the first and second tests, respectively. Approximately $10 \mathrm{ml}$ of the sporangial suspension was delivered per 50 seed pieces. Each treatment consisted of five seed pieces and was replicated 10 times. Pots were arranged on greenhouse benches in a randomized complete block design.

Data analysis. Data were analyzed by analysis of variance (ANOVA) (SAS Institute, Cary, NC). If the $F$ test for treatments was significant at $P \leq 0.05$, mean separation was by least significant difference (LSD). In the case of the laboratory experiment, percent data in each test were analyzed separately using Proc Univariate in SAS in order to determine normality. Appropriate transformations were then assigned according to Kirk (12). For both Oregon and Washington field and greenhouse tests, the number of tested treatments was actually greater than those reported here. Hence, the ANOVAs and subsequent mean separation tests referred to in this report include only those for registered fungicides; data regarding nonregistered and experimental fungicides were excluded from these analyses.

\section{RESULTS}

Laboratory experiment. The amount of tuber surface area colonized by $P$. infestans was significantly $(P \leq 0.05)$ less on blighted seed pieces treated with the two fungicides compared with nontreated blighted seed pieces in five out of six tests (Table 1). Sporangia production by $P$. infestans occurred predominantly on the cut surfaces of seed pieces rather than on the remaining periderm. Treatment with thiophanate-methyl + mancozeb resulted in significantly $(P \leq 0.05)$ less colonization by $P$. infestans than treatment with thiophanate-methyl or no treatment for all three cultivars except for Red LaSoda in test 1 . The overall reduction in colonization relative to the nontreated control amounted to $8.1,58.5$, and $34.4 \%$ using thiophanate-methyl, and 98.8, 77.5, and 
96.9\% using thiophanate-methyl + mancozeb for Russet Burbank, Red LaSoda, and Russet Norkotah, respectively.

Nontreated naturally infected tubers of Red LaSoda had more surface area colonized by $P$. infestans ( $44.7 \%$ across tests) than did nontreated inoculated tubers of Russet Burbank and Russet Norkotah (9.4\% across tests). With the thiophanatemethyl + mancozeb seed piece treatment, $10.0 \%$ of the total surface on naturally infected seed pieces was colonized by $P$. infestans compared with $0.2 \%$ of the tuber surface on artificially inoculated seed pieces. In the naturally infected tubers, thiophanate-methyl + mancozeb outperformed thiophanate-methyl in one out of two tests. In the artificially inoculated group, thiophanate-methyl + mancozeb outperformed thiophanate-methyl in four out of four tests.

Field experiment. Curative applications of fungicides to blighted seed pieces did not significantly $(P=0.05)$ increase emergence relative to the noninoculated controls in field tests in Oregon and Washington (Fig. 1A and B). However, at both locations on three potato cultivars and with two genotypes of $P$. infestans, thiophanate-methyl + mancozeb significantly $(P \leq 0.05)$ increased emergence of blighted seed pieces compared with thiophanate-methyl.

In Oregon, where two cultivars were evaluated, the cultivar by fungicide interaction was not significant. Average emergence across inoculated treatments (data combined) was $21 \%$ for Russet Norkotah and 39\% for Russet Burbank; average emergence across noninoculated treatments (data combined) was $99 \%$ for Russet Norkotah and $98 \%$ for Russet Burbank. Average emergence across the two cultivars was 23,16 , and $38 \%$ for the inoculated-nontreated control, inoculated-thiophanate-methyl, and inoculated-thiophanate-methyl + mancozeb treatments, respectively (Fig. 1A). In Oregon, plants from seed pieces treated with thiophanatemethyl + mancozeb were observed to be more vigorous and not as stunted compared with those treated with thiophanate-methyl. Seven days after emergence, sporulating lesions of late bight were observed at the base of two plants in plots planted with blighted seed pieces of nontreated Russet Norkotah and on one plant in a plot planted with blighted thiophanate-methyl-treated seed pieces of Russet Burbank.

In Washington, emergence was 22 and $9 \%$ for the inoculated thiophanate-methyl + mancozeb and the inoculated thiophanate-methyl treatments (Fig. 1B), respectively. Emergence of noninoculated thiophanate-methyl + mancozeb-treated seed pieces averaged 93\%. Early and severe onset of late blight in Washington precluded determination of whether lesions on emerging sprouts arose from tuber-borne or airborne inoculum.
Greenhouse experiments. Healthy seed pieces inoculated with $P$. infestans resulted in a reduction in stand in both Oregon and Washington greenhouse tests. Emergence at both locations (data combined) averaged $100 \%$ for the noninoculated control compared with $10 \%$ for the inoculated control (Fig. 2A and B).

Table 1. Percent surface area of naturally infected or inoculated potato seed pieces colonized by Phytophthora infestans following treatment with or without an ethylenebisdithiocarbamate fungicide (mancozeb) in laboratory tests

\begin{tabular}{|c|c|c|c|c|c|c|}
\hline \multirow{3}{*}{$\begin{array}{l}\text { Seed piece } \\
\text { fungicide treatment }\end{array}$} & \multicolumn{6}{|c|}{$\%$ Colonized surface area $^{w}$} \\
\hline & \multicolumn{3}{|c|}{ Russet Burbank $^{y}$} & \multicolumn{2}{|c|}{ Red LaSoda ${ }^{z}$} & \multirow{2}{*}{$\begin{array}{l}\text { Norkotah } \\
\text { Test } 1\end{array}$} \\
\hline & Test 1 & Test 2 & Test 3 & Test 1 & Test 2 & \\
\hline $\begin{array}{l}\text { Thiophanate-methyl } \\
\text { + mancozeb }\end{array}$ & $0.0 \mathrm{a}$ & $0.3 \mathrm{a}$ & $0.0 \mathrm{a}$ & $6.3 \mathrm{a}$ & $13.8 \mathrm{a}$ & $0.4 \mathrm{a}$ \\
\hline Thiophanate-methyl & $5.8 \mathrm{~b}$ & $6.3 \mathrm{~b}$ & $10.8 \mathrm{~b}$ & $11.3 \mathrm{a}$ & $25.8 \mathrm{~b}$ & $8.4 \mathrm{~b}$ \\
\hline Nontreated control & $13.0 \mathrm{c}$ & $7.8 \mathrm{c}$ & $4.0 \mathrm{~b}$ & $40.0 \mathrm{~b}$ & $49.4 \mathrm{c}$ & $12.8 \mathrm{c}$ \\
\hline
\end{tabular}

${ }^{w}$ Numbers in the same column followed by the same letter are not significantly different from each other as indicated by least significant difference $(P<0.05)$ of transformed data. Data back-transformed for presentation.

${ }^{\mathrm{x}}$ Fungicides were applied at label rates to blighted seed pieces

y Reciprocal transformation of percent data according to Kirk (12).

${ }^{\mathrm{z}}$ Square root transformation of percent data according to Kirk (12).

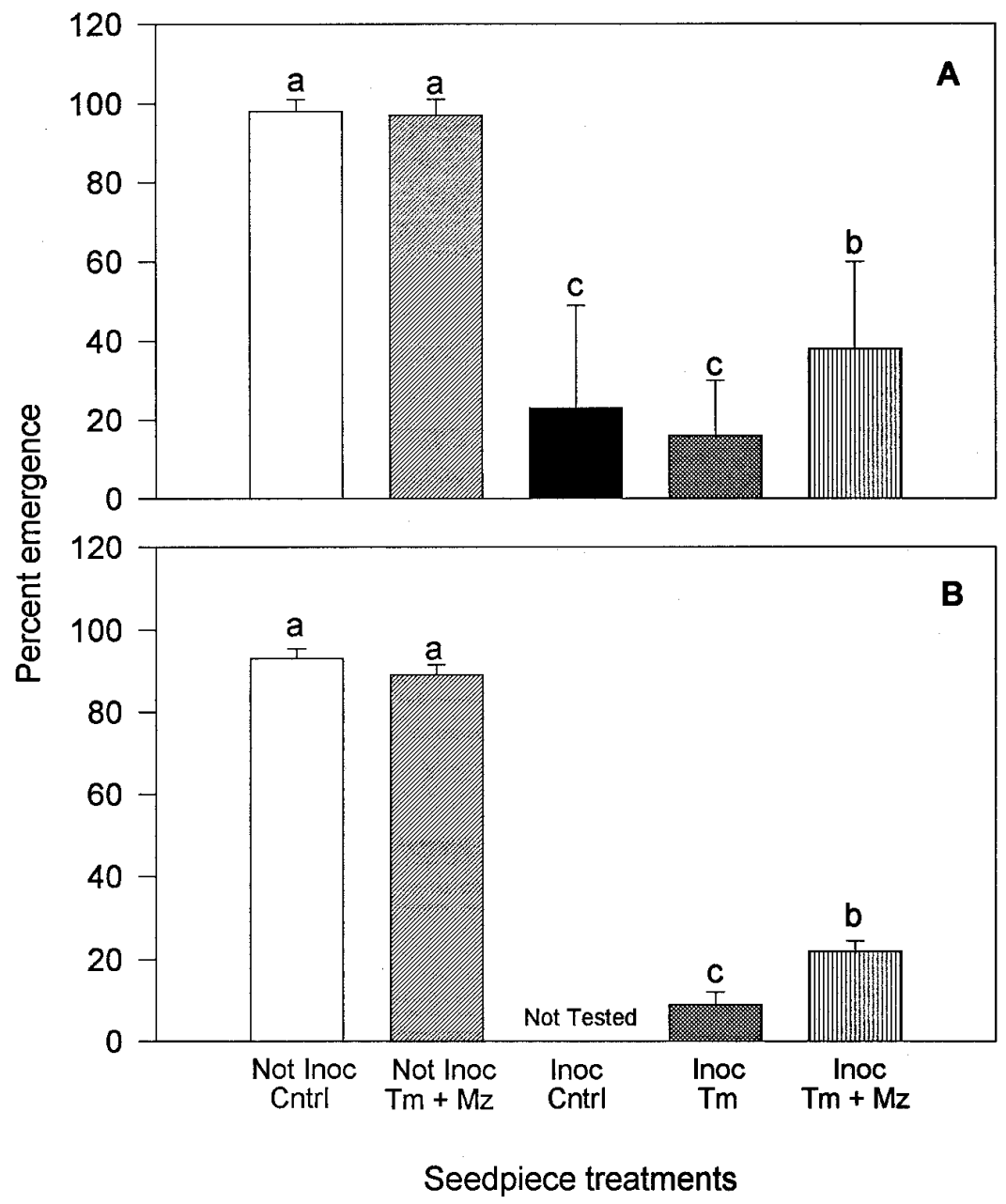

Fig. 1. Effect of potato seed piece fungicide treatments on emergence of late blight infected potato seed pieces in field tests in (A) Oregon and (B) Washington. Genotypes of Phytophthora infestans and potato cultivar were US-8 and Russet Burbank and Russet Norkotah (data combined) in Oregon, and US-11 and White Rose in Washington. Inoc $=$ inoculated. Cntrl $=$ control. Tm $=$ thiophanatemethyl. $\mathrm{Mz}=$ mancozeb. 

+ mancozeb or mancozeb treatments. Emergence at both locations (data combined) averaged $91 \%$ with thiophanatemethyl + mancozeb; whereas emergence averaged $30 \%$ with fludioxinil. Moreover, in Oregon (Fig. 2A), emergence with thiophanate-methyl was significantly $(P \leq$ $0.05)$ lower than with mancozeb, and in Washington (Fig. 2B), emergence with both fludioxinil and thiophanate-methyl was significantly $(P \leq 0.05)$ lower than with mancozeb and thiophanate-methyl + mancozeb. In Washington, emergence with both thiophanate-methyl and fludioxinil was not significantly $(P \leq 0.05)$ different from the inoculated control. Thiophanatemethyl seed piece treatment gave 84 versus $20 \%$ emergence in Oregon and Washington, respectively.

The additional greenhouse experiment in Washington included both treated and nontreated seed pieces, subsequently inoculated with $P$. infestans or water. Percent emergence of treated seed pieces inoculated with $P$. infestans was significantly $(P$ $=0.05$ ) higher for thiophanate-methyl +
$(P \leq 0.05)$ less than the thiophanate-methyl

mancozeb than for thiophanate-methyl or no treatment (Table 2). Tubers treated with thiophanate-methyl or not treated prior to inoculation had similar $(P \leq 0.05)$ emergence in both tests. Percent emergence of inoculated seed pieces previously treated with thiophanate-methyl + mancozeb or mancozeb, and mancozeb or thiophanatemethyl was the same $(P \leq 0.05)$ in test 1 ; in test 2 , this was true for thiophanatemethyl + mancozeb and mancozeb but not for mancozeb and thiophanate-methyl. Across tests (data combined), average emergence of thiophanate-methyl + mancozeb was $89 \%$; whereas average emergence of thiophanate-methyl was $55 \%$. With the protective application of thiophanate-methyl + mancozeb, emergence was similar (89 and 85\%) for either inoculated or noninoculated seed pieces. Stem lesions caused by $P$. infestans were not observed on plants when this experiment ended. When treated seed pieces were not inoculated, there was no significant difference among fungicides in either test 1 or test 2 . Noninoculated-nontreated seed pieces had significantly $(P \leq 0.05)$ higher percent

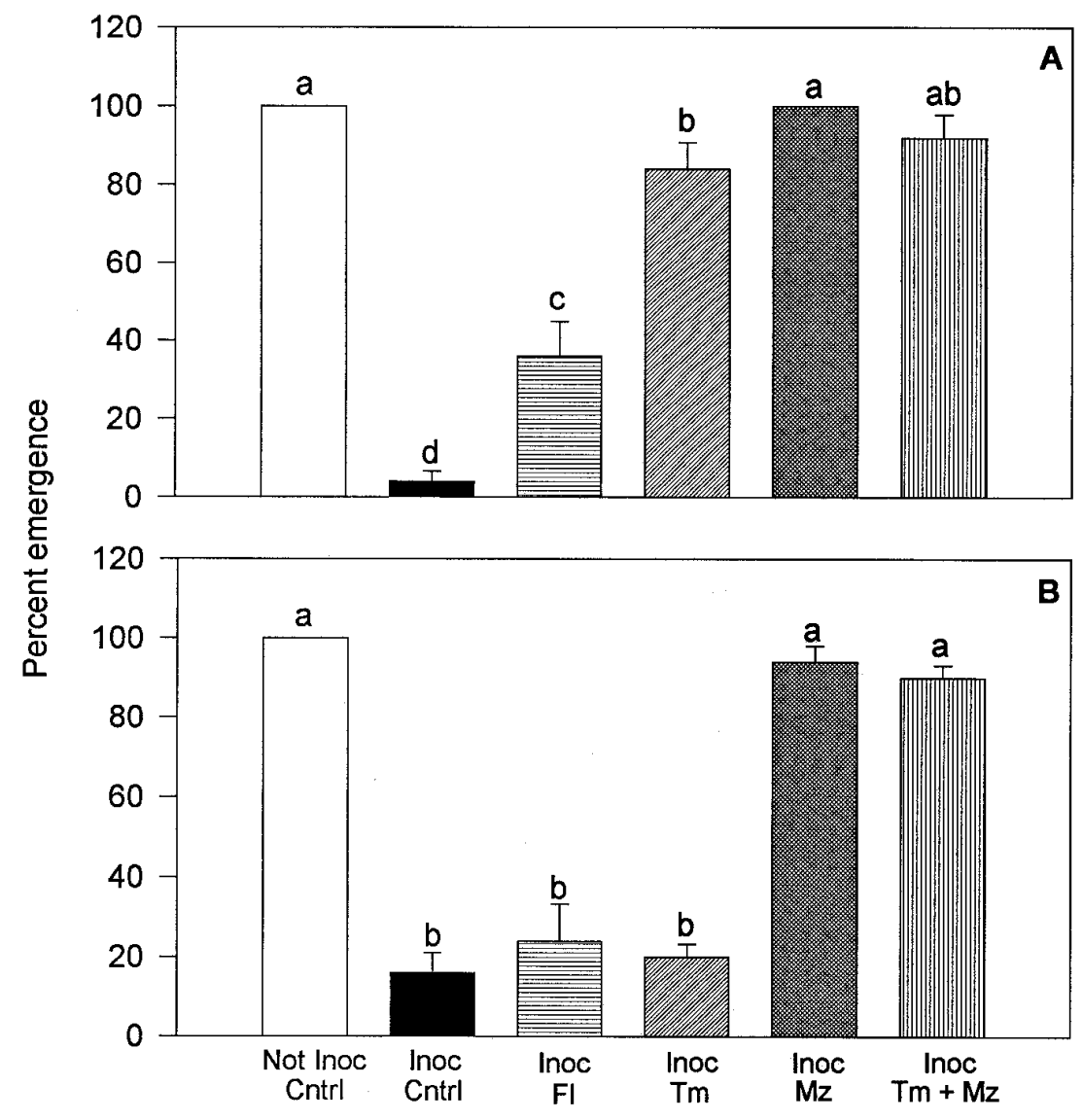

Seedpiece treatments

Fig. 2. Effect of potato seed piece fungicide treatments on emergence of potato seed pieces inoculated with Phytophthora infestans following fungicide treatment in greenhouse tests in (A) Oregon and (B) Washington. Genotypes of $P$. infestans and potato cultivar were US-8 and Russet Burbank in Oregon, and US-11 and White Rose in Washington. Inoc $=$ inoculated. Cntrl $=$ control. Fl $=$ fludioxinil. $\mathrm{Tm}=$ thiophanate-methyl. $\mathrm{Mz}=$ mancozeb. emergence than did noninoculated-treated seed pieces in test 1 , but in test 2 this difference was not apparent.

\section{DISCUSSION}

Treatment of blighted seed pieces with thiophanate-methyl + mancozeb significantly $(P \leq 0.05)$ increased emergence compared with treatment with thiophanatemethyl on three potato cultivars in Oregon and Washington field and greenhouse experiments with isolates representing US-8 and US-11 genotypes (9) of $P$. infestans. Mancozeb is an EBDC fungicide often used for controlling $P$. infestans on potato foliage, and has activity against a broad spectrum of fungi including Phytophthora (16). Mancozeb alone or in combination with thiophanate-methyl was effective against tuber-borne $P$. infestans in greenhouse tests in this study. Although thiophanate-methyl is used in commercial potato seed piece treatment products for suppression of Fusarium spp. and Rhizoctonia solani, it does not suppress oomycete fungi (4). In this study, thiophanate-methyl used without mancozeb was not very effective against tuber-borne $P$. infestans. Fludioxinil is a new seed dressing that has recently been registered on potato for control of Fusarium dry rot, black scurf, and silver scurf, but fludioxinil likewise had no activity against tuber-borne $P$. infestans in this study.

The effect of existing seed treatment fungicides against tuber-borne $P$. infestans is important for three reasons. First, commercially treated seed pieces (leavings) are sometimes discarded near potato fields when seed boxes on planters are cleaned following planting. If diseased seed pieces are not treated or are treated with a fungicide that has no activity or limited activity against late blight and then placed in these cull piles, the fungus may sporulate on the seed pieces. The cull piles then can serve as a source of initial inoculum for establishment of late blight in surrounding fields. Blighted seed pieces treated only with thiophanate-methyl in the laboratory experiment had more of the tuber surface area colonized by $P$. infestans than did seed pieces treated with thiophanate-methyl + mancozeb. Sporulating lesions were noted on sprouts from blighted tubers treated with thiophanate-methyl in the Oregon field test.

Second, the amount of tuber surface area colonized by $P$. infestans US-11 in the laboratory tests differed between naturally infected and inoculated tubers. All three cultivars used in the laboratory tests had been stored in the same facility for 6 months prior to the tests, and tubers of all three cultivars generally are regarded as susceptible to $P$. infestans $(5,11)$. Yet the nontreated naturally infected tubers of Red LaSoda had more surface area $(44.7 \%$ across tests) colonized by $P$. infestans than did nontreated inoculated tubers of Russet 
Burbank and Russet Norkotah $(9.4 \%$ across tests). However, tubers of Red LaSoda had blight at harvest and were incubated for 6 months prior to treatment. In contrast, 6-month-old tubers of Russet Burbank and Russet Norkotah were inoculated and incubated for 1 week. The fact that some tubers of Red LaSoda had not broken down after 6 months of storage may be significant in western Washington potato production, where US-11 has been and continues to be an important component of the $P$. infestans population (6). D. Lambert (personal communication) has shown that US-11 is not as aggressive on potato tubers as US-8. It is possible that US-11 retains a competitive advantage in western Washington because it has the ability to colonize but not necessarily destroy the tuber during storage. The efficiency of different fungicides as tuber surface protectants in relation to type of inoculum, inoculation method, time of infection, and timing of inoculation and infection relative to timing of fungicide treatment warrants further exploration.

Third, whenever spores accumulate on the surface of a tuber, the opportunity exists for transfer of the pathogen from diseased to healthy tissue. Lambert and Currier (13) showed with US-8 that cut surfaces of potato seed pieces are particularly susceptible to infection and produce abundant sporangia. We also noted more mycelial growth and sporulation by $P$. infestans on cut surfaces of seed pieces than on the periderm. In addition, sporangia of $P$. infestans can be moved during the instorage handling process (7) and during loading, unloading, piling, cutting, and other handling operations (14).

The performance of seed piece fungicides that target $P$. infestans and are used to protect seed pieces from contamination by $P$. infestans during handling operations ficial, than the same seed piece fungicides used in a curative way to control estabmay be different, and possibly more bene-

lished infections. In this study, a curative application of thiophanate-methyl + mancozeb to blighted seed pieces did not result in emergence similar to the noninoculated control; whereas a protective application of thiophanate-methyl + mancozeb to healthy seed pieces later inoculated with $P$. infestans did result in emergence similar to the noninoculated control. Whether the plants from seed pieces treated with a protective application of fungicide prior to inoculation would have developed symptoms of late blight is not known, as the greenhouse experiments were terminated early when the plants outgrew the pots. Nevertheless, when the experiments were terminated, after the plants had received high humidity or mist treatment, stem lesions were not observed.

Deahl (3) reported that inactive or actively growing sprouts in contact with spores of $P$. infestans can give rise to plants with symptoms of late blight. Since late blight can increase exponentially (17), even a small number of plants supporting lesions of late blight that presumably originate from the seed piece can contribute to the epidemiology of the disease (10). Transmission of late blight from an infected seed piece to the developing sprout was observed with US-8 on a few plants of Russet Burbank and Russet Norkotah in the field in Oregon. Transmission of US-11 was not observed in the field in Washington, but airborne inoculum may have confounded observations. Marshall and Stevenson (15) showed that the probability for transmission of $P$. infestans from the seed tuber to the sprout was much higher for US-8 than for US-1. Furthermore, US-6, US-7, and US- 8 have been shown to be more aggressive to potato tubers than the previously existing genotype, US-1 (13). However, many factors could affect transmission efficiency, particularly depth of planting and soil moisture. These factors need to be explored as potential management tools.

Table 2. Percent emergence of healthy potato seed pieces inoculated or not inoculated with Phytophthora infestans (US-11) following treatment with and without an ethylenebisdithiocarbamate fungicide (mancozeb) in greenhouse tests

\begin{tabular}{llll}
\hline Seed pieces & Fungicides & Test $\mathbf{1}^{\mathbf{y}}$ & Test $^{\mathbf{y}}$ \\
\hline Inoculated $^{\mathrm{z}}$ & Thiophanate-methyl + mancozeb & $86 \mathrm{a}$ & $92 \mathrm{a}$ \\
& Mancozeb & $66 \mathrm{ab}$ & $94 \mathrm{a}$ \\
& Thiophanate-methyl & $46 \mathrm{bc}$ & $64 \mathrm{~b}$ \\
& Not treated & $38 \mathrm{c}$ & $58 \mathrm{~b}$ \\
Not inoculated $^{z}$ & LSD $(P=0.05)$ & 20.8 & 14.9 \\
& Thiophanate-methyl + mancozeb & $80 \mathrm{a}$ & 90 \\
& Mancozeb & $66 \mathrm{a}$ & 86 \\
& Thiophanate-methyl & $78 \mathrm{a}$ & 96 \\
& Not treated & $98 \mathrm{~b}$ & 96 \\
& LSD $(P=0.05)$ & 14.2 & NSD \\
\hline
\end{tabular}

${ }_{\mathrm{y}}$ Test 1 was done in November 1997 with seed tubers of White Rose produced during the 1996 growing season; test 2 was done in February 1998 with seed tubers of White Rose produced during the 1997 growing season. Means in the same column within the same inoculation group followed by the same letter are not significantly different $(P \leq 0.05)$ according to least significant difference (LSD). NSD = not significantly different.

${ }^{\mathrm{z}}$ Fungicide-treated seed pieces inoculated with suspension of $10^{3}$ sporangia per ml of US-11 P. infestans $(10 \mathrm{ml}$ per 50 seed pieces $)$; not inoculated $=$ atomized with distilled water.
Commercial seed piece fungicide products that include an EBDC as an active ingredient are effective against tuber-borne inoculum of late blight. Conversely, other seed piece fungicides like thiophanatemethyl and fludioxinil, which do not target $P$. infestans, may indirectly allow the transmission of $P$. infestans from the seed piece to the developing sprout, not only because they lack efficacy against $P$. infestans, but because they suppress tuber surface microorganisms such as Fusarium spp. that may compete with $P$. infestans on the tuber surface. Certain microorganisms have been reported to influence the susceptibility of potato tubers to late blight (2). We noted in our laboratory experiment that in the absence of other microorganisms such as bacteria and Fusarium spp., sporulation of $P$. infestans on seed pieces was much easier to detect.

Treatment of seed pieces with fungicides effective against $P$. infestans could help protect against the infections that occur during cutting and handling operations when seed pieces with sporulating lesions come into contact with healthy seed. Seed piece treatment at this time would minimize tuber-to-tuber contamination. Effective seed piece treatments also could reduce sporulation of $P$. infestans on contaminated seed pieces when they are placed in cull piles. These same fungicides, however, will not cure seed pieces that are infected with $P$. infestans, nor will they protect emerging sprouts from airborne inoculum of this pathogen. But they should reduce or eliminate the transmission of $P$. infestans to healthy seed pieces, whether or not they limit the occurrence of the disease.

\section{ACKNOWLEDGMENTS}

This research was supported, in part, by grants from the National Potato Council, the Washington State Potato Commission, the Oregon Potato Commission, and Gustafson, Inc. We thank Dennis Johnson, Kathy Merryfield, and Robert Spotts for their critical reading of the manuscript. We also thank B. Gundersen, R. Ludy, M. Derie, and E. Vestey for technical assistance. Plant Pathology new series no. 0276, project 0123, Washington State University, College of Agriculture and Home Economics Research Center, Washington State University, Pullman.

\section{LITERATURE CITED}

1. Bruck, R. I., Fry, W. E., Apple, A. E., and Mundt, C. C. 1981. Effect of protectant fungicides on the developmental stages of Phy tophthora infestans in potato foliage. Phytopathology 71:164-166.

2. Clulow, S. A., Stewart, H. E., Dashwood, E. P., and Wastie, R. L. 1995. Tuber surface microorganisms influence the susceptibility of potato tubers to late blight. Ann. Appl. Biol. 126:33-43.

3. Deahl, K. L. 1995. Potato tubers role in the late blight complex. Pages 10-14 in: Proc. Annu. Nat. Potato Council Sem., 14th.

4. Dekkar, J. 1993. The fungicide resistance problem: Current status and the role of systemics. Pages 163-180 in: Pesticide Interactions in Crop Production. J. Altman, ed. CRC Press, Boca Raton, FL. 
5. Dorrance, A. E., and Inglis, D. A. 1998. Assessment of laboratory methods for evaluating potato tubers for resistance to late blight. Plant Dis. 82:442-446.

6. Dorrance, A. E., Inglis, D. A., Derie, M. L., Brown, C. R., Goodwin, S. B., Fry, W. E., and Deahl, K. L. 1999. Characterization of Phytophthora infestans populations in western Washington. Plant Dis. In press.

7. Dowley, L. J., O'Sullivan, E., and Kehoe, H. W. 1991. Development and evaluation of blight resistant potato cultivars. Pages 373-381 in: Phytophthora. J. A. Lucas, R. C. Shattock, D. S. Shaw, and L. R. Cooke, eds. Cambridge University Press, Cambridge.

8. Fry, W. E., Goodwin, S. B., Dyer, A. T., Matuszak, J. M., Drenth, A., Tooley, P. W., Sujkowski, L. S., Koh, Y. J., Cohen, B. A., Spielman, L. J., Deahl, K. L., Inglis, A. D., and Sandlan, K. P. 1993. Historical and recent migrations of Phytophthora infestans: Chronology, pathways, and implications. Plant Dis. 77:653-661.

9. Goodwin, S. B., Cohen, B. A., Deahl, K. L., and Fry, W. E. 1994. Migration from Northern Mexico as the probable cause of recent genetic changes in populations of Phytophthora infestans in the United States and Canada. Phytopathology 84:553-558.

10. Hirst, J. M., and Stedman, O. J. 1960. The epidemiology of Phytophthora infestans. II. The source of inoculum. Ann. Appl. Biol. 48:489-517.

11. Inglis, D. A., Johnson, D. A., Legard, D. E., Fry, W. E., and Hamm, P. B. 1996. Relative resistances of potato clones in response to new and old populations of Phytophthora infestans. Plant Dis. 80:575-578.

12. Kirk, R. E. 1982. Experimental Design: Pro- cedures for the Behavioral Sciences. 2nd ed. Brooks/Cole Publishing Company, Monterey, CA. pp. 82-84.

13. Lambert, D. H., and Currier, A. I. 1997. Differences in tuber rot development for North American clones of Phytophthora infestans. Am. Potato J. 74:39-43.

14. Lambert, D. H., Currier, A. I., and Olanya, M. 1998. Transmission of Phytophthora infestans in cut potato seed. Am. J. Potato Res. 75:257263.

15. Marshall, K. D., and Stevenson, W. R. 1996. Transmission of $P$. infestans from infected seed potato tubers to developing sprouts. (Abstr.) Am. Potato J. 73:370-371.

16. Thomson, W. T. 1993. Agricultural Chemicals. Book IV. Fungicides. Thomson Publications, Fresno, CA.

17. Vanderplank, J. E. 1975. Principles of Plant Infection. Academic Press, New York. 